\title{
Effects of pressurized thermal processing on native proteins of raw skim milk and its concentrate
}

\author{
Dimuthu Bogahawaththa, ${ }^{1 *}$ Biljana Trajkovska, ${ }^{2}$ Tatijana Markoska, ${ }^{1}$ and Todor Vasiljevic ${ }^{1}$ \\ ${ }^{1}$ Advanced Food Systems Research Unit, Institute of Sustainable Industries and Liveable Cities and College of Health and Biomedicine, \\ Victoria University, Werribee Campus, Victoria 3030, Australia \\ ${ }^{2}$ Faculty of Biotechnical Sciences, University "St. Kliment Ohridski," Bitola 7000, Macedonia
}

\section{ABSTRACT}

Heating, pressurization, and shearing can modify native milk proteins. The effects of pressurized heating ( 0.5 vs. $10 \mathrm{MPa}$ at 75 or $\left.95^{\circ} \mathrm{C}\right)$ with shearing $\left(1,000 \mathrm{~s}^{-1}\right)$ on proteins of raw bovine skim milk (SM, $\sim 9 \%$ total solids) and concentrated raw skim milk (CSM, $\sim 22 \%$ total solids) was investigated. The effects of evaporative concentration at $55^{\circ} \mathrm{C}$ and pressurized shearing (10 $\mathrm{MPa}, 1,000 \mathrm{~s}^{-1}$ ) at $20^{\circ} \mathrm{C}$ were also examined. Evaporative concentration of SM resulted in destabilization of casein micelles and dissociation of $\alpha_{\mathrm{S1}^{-}}$and $\beta$-casein, rendering CSM prone to further reactions. Treatment at $10 \mathrm{MPa}$ and $1,000 \mathrm{~s}^{-1}$ at $20^{\circ} \mathrm{C}$ caused substantial dissociation of $\alpha_{\mathrm{S}^{-}}$and $\beta$-casein in SM and CSM, with some dissociated caseins forming shear-induced soluble aggregates in CSM. The pressure applied at $10 \mathrm{MPa}$ induced compression of the micelles and their dissociation in SM and CSM at 75 or $95^{\circ} \mathrm{C}$, resulting in reduction of the micelle size. However, $10 \mathrm{MPa}$ did not alter the mineral balance or whey proteins denaturation largely, except by reduction of some $\beta$-sheets and $\alpha$-helices, due to heat-induced conformational changes at 75 and $95^{\circ} \mathrm{C}$.

Key words: pressure, heat, shear, casein micelle

\section{INTRODUCTION}

Heat treatments are commonly applied to raw bovine milk in the dairy industry to achieve microbial safety and to extend shelf life (e.g., pasteurization and sterilization) or as a preparatory step to enhance the functional properties of some dairy products (e.g., cheese and yogurt). Heating of milk, mostly above $70^{\circ} \mathrm{C}$, can result in physicochemical changes to proteins, predominantly denaturation and aggregation, depending on temperature and time combination. Unlike

\footnotetext{
Received August 29, 2020.

Accepted November 1, 2020.

*Corresponding author: dimuthu.hewabogahawaththage@live.vu
} .edu.au caseins, whey proteins are relatively heat-labile. Being the most abundant whey protein, $\beta$-LG usually leads heat-induced protein denaturation and subsequent aggregation with other whey proteins, such as $\alpha$-LA, BSA, immunoglobulins, and lactoferrin ( $\mathbf{L F})$, as well as the caseins, mainly $\kappa-\mathrm{CN}$, via thiol, disulfide, electrostatic, and hydrophobic interactions (Patel et al., 2006; Wijayanti et al., 2014; Bogahawaththa et al., 2019).

Concentration of milk by removal of water is an essential step of producing milk powders and other milk concentrates (e.g., evaporated milk and condensed milk), which leads to dissociation of the casein micelles into the serum phase, modification of mineral distribution, conformational changes of whey proteins, and association of $\beta$-LG with the casein micelles (Markoska et al., 2019a). These modifications can lead to further destabilization of the casein micelles and conformational changes of $\beta$-LG during heating, resulting in compromised heat stability of proteins, depending on the concentration level and combination of temperature and time (Huppertz, 2016; Markoska et al., 2019b). The milk can also be subjected to many mechanical forces, including shear, at various steps during commercial thermal processing (e.g., mixing, stirring, pumping, flowing through pipes, and spraying), which can induce whey protein denaturation, influence protein aggregation, and modify the casein micelles (Mediwaththe et al., 2018a; Bogahawaththa and Vasiljevic, 2020).

Application of high hydrostatic pressure (HHP), especially at higher levels (100-1,000 MPa), has been recognized as a promising nonthermal method for pasteurization and sterilization of dairy products and for modification of the functional properties of milk proteins. However, HHP treatments can result in denaturation of whey proteins and their interaction with other proteins to a varying degree, depending on protein type and the combination of pressure and holding time. $\alpha$-LA is the most pressure-stable $\left(>400 \mathrm{MPa}\right.$ at $40^{\circ} \mathrm{C}$ for $30 \mathrm{~min}$ ), and $\beta$-LG appears to be the most pressuresensitive $\left(>100 \mathrm{MPa}\right.$ at $4^{\circ} \mathrm{C}$ for $30 \mathrm{~min}$; Huppertz et al., 2004b). $\beta$-LG tends to form aggregates mainly with $\kappa-\mathrm{CN}$ at $\geq 600 \mathrm{MPa}$ (Huppertz et al., 2004b; Patel et 
al., 2006; Bogahawaththa et al., 2018). Furthermore, HHP treatments at $>200 \mathrm{MPa}$ can modify the casein micelle size. For instance, the micelle size increased $(\sim 25 \%)$ reversibly at $250 \mathrm{MPa}$ but decreased $(\sim 50 \%)$ irreversibly at $\geq 300 \mathrm{MPa}$ in raw skim milk (SM; Huppertz et al., 2004b). Pressurization (HHP) of raw SM at the level of 100 to $600 \mathrm{MPa}$ caused the increase of $\alpha_{S^{-}}$and $\beta-C N$ in the serum phase due to weakening of hydrophobic interactions and solubilization of colloidal calcium phosphate (CCP; Huppertz et al., 2004a).

The application of pressure $(>100 \mathrm{MPa})$ combined with moderate temperature $\left(40-70^{\circ} \mathrm{C}\right)$ can modify the physicochemical properties of milk proteins differently than a pressure treatment at $\leq 30^{\circ} \mathrm{C}$. For instance, pressurization at 200 to $800 \mathrm{MPa}$ with $70^{\circ} \mathrm{C}$ resulted in significantly greater denaturation of $\beta-\mathrm{LG}$ and $\alpha-\mathrm{LA}$ and larger particle size in reconstituted SM compared with to the corresponding pressure treatments performed at $20^{\circ} \mathrm{C}$ (Anema, 2008). When SM was pressurized at 100 to $300 \mathrm{MPa}$ at different temperature levels $\left(25-60^{\circ} \mathrm{C}\right)$, the increase in temperature resulted in gradual increase in denaturation of $\beta$-LG at the respective pressure levels (López-Fandiño and Olano, 1998b). When raising the temperature from 10 to $40^{\circ} \mathrm{C}$ at $200 \mathrm{MPa}$, the particle size of SM increased due to protein aggregation, whereas at $\geq 400 \mathrm{MPa}$ the degree of disintegration of the casein micelle increased (Anema et al., 2005).

According to the existing literature (Anema, 2008; Huppertz et al., 2019; Nunes and Tavares, 2019; Wijayanti et al., 2019), it appears that no scientific studies have investigated the effects of low pressure $(\leq 10$ $\mathrm{MPa})$ combined with heating $\left(>70^{\circ} \mathrm{C}\right)$ and shearing on native and concentrated milk proteins. However, such combinations are frequently applied in milk processing, especially heating the milk at $>100^{\circ} \mathrm{C}$ and milk homogenization $\left(55-80^{\circ} \mathrm{C}\right.$ and $10-25 \mathrm{MPa}$; Bylund, 2003). For instance, UHT treatment $\left(138-145^{\circ} \mathrm{C}\right.$ for $\left.3-5 \mathrm{~s}\right)$ is performed under pressurized conditions $(\sim 0.4 \mathrm{MPa}$; Deeth and Datta, 2011). Hence, the current study aimed to examine the effects of pressurized (10 vs. $0.5 \mathrm{MPa}$ ) heat treatments $\left(75\right.$ or $\left.95^{\circ} \mathrm{C}\right)$ with a constant shearing $(1,000$ $\mathrm{s}^{-1}$ ) on physicochemical and structural changes to native proteins of raw SM and its concentrate. Findings of this work will help in the development or optimization of thermal processing parameters to achieve desired product characteristics.

\section{MATERIALS AND METHODS}

\section{Sample Preparation}

Murray Goulburn Cooperative Co. Ltd. (Laverton North, VIC, Australia) kindly provided raw bovine milk. Upon delivery, the milk was skimmed by centrifu- gation, and sodium azide at $0.01 \%$ (wt/wt) was added to control potential microbial activities (Markoska et al., 2019a). The standard oven drying method $\left(105^{\circ} \mathrm{C}\right)$ was used to determine TS content of the resultant SM, which was $9 \pm 0.3 \%$ (wt/wt). The SM was then divided into 2 portions, one of which was concentrated by evaporation at $55^{\circ} \mathrm{C}$ for about 100 min using an R-100 rotary evaporator (John Morris Scientific, Deepdene, VIC, Australia) as described previously (Markoska et al., 2019a) to obtain skim milk with $22 \pm 0.2 \%$ (wt/wt) TS, which was termed concentrated skim milk (CSM).

\section{Sample Treatment}

Both SM and CSM samples were heated to 2 temperature levels $\left(75\right.$ or $95^{\circ} \mathrm{C}$ ) at a $\sim 5^{\circ} \mathrm{C} / \mathrm{min}$ heating and cooling rate under 2 low-pressure conditions (0.5 or $10 \mathrm{MPa}$ ) using a cup-and-bob geometry (CC 25/ PR-SN; Anton Paar, Ostfildern, Germany) placed in a pressure cell (CC25/PR-150; Anton Paar) mounted on a Physica MCR 301 rheometer (Anton Paar), as explained previously (Mediwaththe et al., 2018a). The required pressure levels were generated and maintained using a compressed air system linked to the pressure cell and monitored by an associated software (Rheoplus, Anton Paar). A constant shear at $1,000 \mathrm{~s}^{-1}$ was applied with all the treatments, and the cooling process was terminated at room temperature $\left(\sim 20^{\circ} \mathrm{C}\right)$. Another aliquot of SM and CSM was pressurized to $10 \mathrm{MPa}$ at $20^{\circ} \mathrm{C}$ with constant shearing, using the same system, to examine the combined effects of pressure and shearing. Total treatment times (heating and cooling or holding) at 95,75 , and $20^{\circ} \mathrm{C}$ were $\sim 30,22$, and $20 \mathrm{~min}$, respectively. Untreated samples of SM and CSM at $\sim 20^{\circ} \mathrm{C}$ were considered the controls. After the treatments, an aliquot of all the treated and the control samples was ultra-centrifuged at $100,000 \times g$ for $1 \mathrm{~h}$ at $20^{\circ} \mathrm{C}$ using a Beckman Ultra L-70 (Beckman Coulter Pty Ltd., Lane Cove West, NSW, Australia) to separate the supernatant (serum phase) from the pellet, keeping the other aliquot as the intact milk (termed "bulk milk") before analysis.

\section{Particle Size and Zeta Potential Measurement}

Average particle size and zeta potential of all the treated and control milk samples (bulk milk) was measured at $20^{\circ} \mathrm{C}$ using a Nano-ZS Zetasizer (Malvern Instruments, Malvern, UK) after diluting them in a simulated milk ultrafiltrate as reported previously (Markoska et al., 2019a). Refractive indices of the casein micelle in milk and the simulated milk ultrafiltrate were set at 1.57 and 1.34 , respectively. 


\section{Mineral Content Determination}

Calcium, magnesium, and phosphorus content in all the treated and control milk samples and their serum phases were determined using an ICP Multitype inductively coupled plasma atomic emission spectrometer (Shimadzu Corporation, Kyoto, Japan) as described previously (Markoska et al., 2019a). All the samples were ashed and then dissolved in $1 M$ nitric acid before determining the mineral content.

\section{Polyacrylamide Gel Electrophoresis}

The SDS-PAGE analysis was performed under nonreducing and reducing (using $\beta$-mercaptoethanol) conditions for all the treated and control milk samples and their serum phase following the method explained previously (Bogahawaththa et al., 2017). Gels containing $30 \%$ acrylamide and 10\% SDS were used for electrophoresis, and protein bands were stained with Coomassie Brilliant Blue (Sigma-Aldrich Pty Ltd., Castle Hill, NSW, Australia). The gel images were captured using the ChemiDoc Imaging System (Bio-Rad Laboratories, Gladesville, NSW, Australia).

\section{Fourier-Transform Infrared Spectroscopy}

All the milk samples (treated and control) were scanned using a Frontier Fourier-transform infrared spectrometer (PerkinElmer, Waltham, MA). Every spectrum was an average of 16 scans at $4 \mathrm{~cm}^{-1}$ resolution in absorbance mode with background (water) subtraction. Changes of secondary structure of the proteins were analyzed using second derivative form of all the spectra within broad amide I region $\left(1700-1,600 \mathrm{~cm}^{-1}\right)$ by Spectragryph software (v.1.2.7; Bogahawaththa et al., 2017).

\section{Statistical Analysis}

The entire experiment was replicated with raw milk obtained on 2 different occasions $(\mathrm{n} \geq 6)$. Data were analyzed by ANOVA and Tukey test, considering the level of significance at $P \leq 0.05$, using SAS statistical software (v. 9.2; SAS Institute Inc., Cary, NC).

\section{RESULTS AND DISCUSSION}

\section{Effect of Evaporative Concentration on Milk Proteins}

To investigate the effects of the evaporative concentration process on milk proteins, a comparison was made between the control (untreated) sample of SM ( $9 \% \mathrm{wt} / \mathrm{wt}$ of TS) and the control (without further processing) sample of CSM ( $\sim 22 \%$ wt/wt of TS). Particle size of the control CSM significantly increased (Table 1) compared with the control SM. This can be mainly related to dense packing of the casein micelles during the evaporative concentration and subsequently enhanced protein interactions, especially association of $\beta-\mathrm{LG}$ with the casein micelles (Markoska et al., 2019a). The temperature $\left(55^{\circ} \mathrm{C}\right)$ applied during the evaporative concentration was higher than that $\left(30^{\circ} \mathrm{C}\right)$ required to dissociate $\beta$-LG dimers into monomers and thereby expose hydrophobic sites, leading to increased protein interactions (Wijayanti et al., 2014; Markoska et al., 2019a). Furthermore, a substantial release of $\alpha_{S^{-}}$and $\beta-\mathrm{CN}$ into the serum phase, as observed in the nonreducing SDS-PAGE results (Figure 1, B1 and D1), indicated a considerable dissociation of the casein micelles during the concentration step. This can be attributed to solubilization of CCP as well as to weakening of electrostatic interactions and hydrogen bonding, leading to destabilization of the casein micelles (Markoska et al., 2019a). Anema and Klostermeyer (1997) reported that $\sim 7 \%$ of $\beta-\mathrm{CN}$ and $\sim 5 \%$ of $\alpha_{\mathrm{S}^{-}} \mathrm{CN}$ were in the serum phase of reconstituted SM ( $10 \% \mathrm{wt} / \mathrm{wt}$ of TS) after heating at 50 to $60^{\circ} \mathrm{C}$ for $15 \mathrm{~min}$, and this temperature level had the greatest effect on dissociation of the caseins into the serum phase within the 20 to $100^{\circ} \mathrm{C}$ range. Hence, the $55^{\circ} \mathrm{C}$ applied during the concentration phase also contributed to the dissociation of $\alpha_{\mathrm{S1}^{-}}$and $\beta-\mathrm{CN}$ in the current study. Markoska et al. (2019a) reported similar results to the current study: for instance, increase in size of the casein micelle, increase in the soluble caseins in the serum phase, and related destabilization of the casein micelles when raw SM (9\% wt/wt of TS) was evaporatively concentrated into 17 or $25 \% \mathrm{wt} / \mathrm{wt}$ of TS using the equivalent conditions.

Some structural changes of the protein secondary structures were also observed via Fourier-transform infrared spectrometry (Figure 2) upon concentration. For instance, a slight increase in antiparallel $\beta$-sheets $\left(\sim 1638-1,632 \mathrm{~cm}^{-1}\right)$, aggregated $\beta$-sheets $(\sim 1690-1,685$ $\mathrm{cm}^{-1}$ ), and $\alpha$-helices $\left(\sim 1653-1,651 \mathrm{~cm}^{-1}\right.$ ) (Bogahawaththa et al., 2019; Markoska et al., 2019a) was observed in the control CSM compared with the control SM (Figure $2 \mathrm{~A}$ ). These changes can be related to increased protein concentration and, thereby, close molecular packing (Markoska et al., 2019a). We detected no significant changes of the final mineral balance when the soluble minerals of SM (Table 2: Ca 12.1, Mg 3.6, and P 13.6 $\mathrm{m} M$ ) were compared with concentration-normalized soluble minerals of CSM (Ca 13.5, Mg 3.4, and P 14.5 $\mathrm{m} M)$. A slight increase in $\mathrm{Ca}$ and $\mathrm{P}$ in the serum phase of the control CSM (concentration normalized), compared with the control SM, indicated solubilization of CCP to some extent, which was, however, not promi- 
nent, due to movement of $\mathrm{Ca}$ and $\mathrm{P}$ into the micellar phase during the concentration phase (Nieuwenhuijse et al., 1988). The zeta potential did not change $(P>$ 0.05 ) after the concentration step (Table 1), as reported previously (Markoska et al., 2019a).

\section{Influence of Pressurized Shearing at $20^{\circ} \mathrm{C}$ on Milk Proteins}

Any changes of the proteins that can be observed between the control $\left(\sim 20^{\circ} \mathrm{C}\right)$ and samples of $\mathrm{SM}$ or CSM treated at $10 \mathrm{MPa}$ at $20^{\circ} \mathrm{C}$ with $1,000 \mathrm{~s}^{-1}$ can be related to the combined effect of pressure (10 $\mathrm{MPa})$ and shearing $\left(1,000 \mathrm{~s}^{-1}\right)$. We detected no significant change (only a slight increase) of the particle size of SM or CSM following the $10-\mathrm{MPa}, 20^{\circ} \mathrm{C}$ treatment (Table 1). From the SDS-PAGE nonreducing image (Figure $1, \mathrm{~B} 1)$, slightly intense $\alpha_{\mathrm{S} 1^{-}}$and $\beta-\mathrm{CN}$ bands appeared in the serum phase of the SM treated at $10 \mathrm{MPa}$ and $20^{\circ} \mathrm{C}$ compared with those of the control, whereas the whey protein bands did not change. This indicated that $10 \mathrm{MPa}$ and $20^{\circ} \mathrm{C}$ under shear treatment contributed to destabilization of the casein micelles slightly, which resulted in dissociation of the caseins into the serum phase without altering the micelle size considerably. Because the low pressure applied $(10 \mathrm{MPa})$ at $20^{\circ} \mathrm{C}$ is unlikely to change the micellar structure (Huppertz et al., 2004a; Anema et al., 2005), destabilization of the casein micelles can be ascribed to the applied shear or the combination of shear and pressure. Reversible destabilization of the casein micelle, leading to increase in its size, was reported when raw SM was sheared at $1,000 \mathrm{~s}^{-1}$ and $20^{\circ} \mathrm{C}$ in an equivalent experimental setting, due to fluid grads created by shearing in the flow direction (Mediwaththe et al., 2018a).

In contrast, very faint $\alpha_{\mathrm{S}^{-}}$and $\beta-\mathrm{CN}$ bands were observed from the serum phase of CSM treated at 10
$\mathrm{MPa}$ and $20^{\circ} \mathrm{C}$ under nonreducing SDS-PAGE (Figure 1, D1) compared with those of the control. The intensity of these bands, however, was mostly similar under reducing SDS-PAGE conditions (Figure 1, D2). This suggested that the dissociated caseins were involved in formation of soluble aggregates potentially induced by shearing. Apart from the caseins, it appeared that some whey proteins, especially minor whey proteins (IgG, LF, and BSA), were also involved in this aggregation process, because they displayed relatively more intense bands, as indicated by the reducing SDS-PAGE of the CSM treated at $10 \mathrm{MPa}$ and $20^{\circ} \mathrm{C}$, compared with that of the control (Figure 1, D2). However, the participation of $\beta-\mathrm{LG}$ and $\alpha-\mathrm{LA}$ in the protein aggregation was not obvious under these treatment conditions. The denser molecular packing, particularly of larger molecules such as minor whey proteins (IgG, LF, and BSA), and deterioration of protein stability take place during the concentration step (Markoska et al., 2019a). In addition to this, shear-induced structural modifications (Mediwaththe et al., 2018a,b; Bogahawaththa and Vasiljevic, 2020) can create an environment to induce inter- and intraprotein interactions, leading to their aggregation. Pressurization and shearing at $20^{\circ} \mathrm{C}$ did not change the secondary structure of the proteins in SM or CSM substantially, probably due to least physicochemical changes in major whey proteins $(\beta-\mathrm{LG}$ and $\alpha$-LA), as discussed above. However, some reduction of the antiparallel $\beta$-sheets and $\alpha$-helices was observed that can be related to the dissociation of $\beta$-LG dimers into monomeric form (Lefèvre and Subirade, 1999) and partial unfolding of the native conformation of $\beta$-LG induced by shearing (Mediwaththe et al., 2018a). The soluble $\mathrm{Ca}, \mathrm{Mg}$, and $\mathrm{P}$ in $\mathrm{SM}$ and CSM largely decreased following the pressurized shear treatment, compared with those of the control, possibly due to shifting of the mineral balance induced by shear. Similar to the

Table 1. The average particle size and zeta potential of skim milk and concentrated skim milk samples subjected to different pressurized thermal treatments

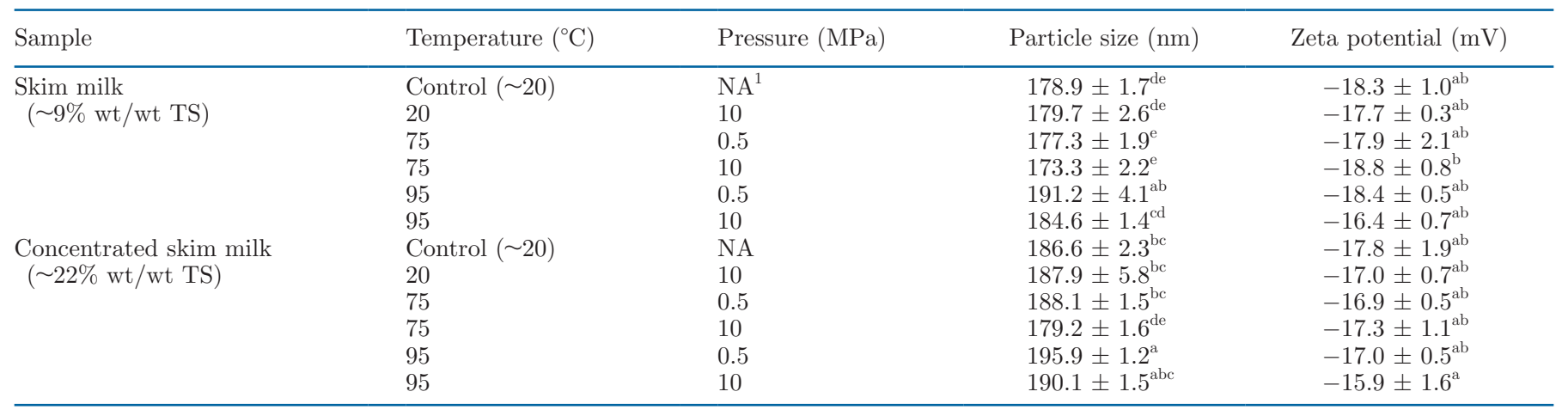

${ }^{\mathrm{a}-\mathrm{e}}$ Mean values without a common superscript letter in the same column indicate significant difference $(P \leq 0.05)$.

${ }^{1} \mathrm{NA}=$ not applicable. 


\section{Skim milk (SM)}

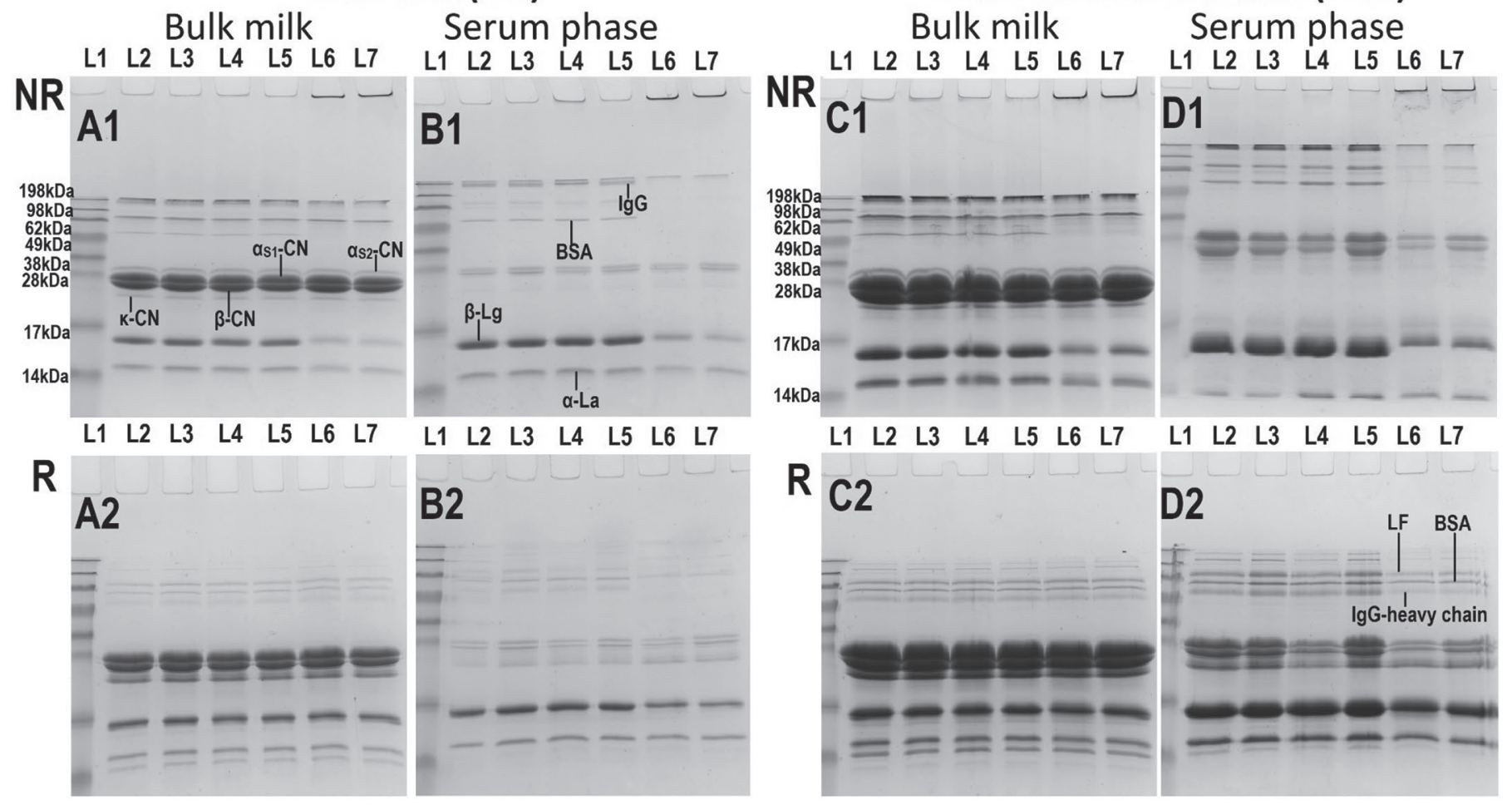

Figure 1. Sodium dodecyl sulfate-PAGE images of skim milk (SM) and concentrated skim milk (CSM) samples (bulk milk) subjected to different pressurized thermal treatments and their supernatants (serum phase) obtained via ultracentrifugation after treatments. A1 and C1 are the SM and CSM bulk samples, and B1 and D1 are their serum phases, respectively, under nonreducing (NR) conditions. A2, B2, C2, and D2 are the corresponding reducing $(\mathrm{R})$ images. Lanes $(\mathrm{L})$ are as follows: $\mathrm{L} 1=$ molecular weight marker, $\mathrm{L} 2=\mathrm{control}, \mathrm{L} 3=10 \mathrm{MPa}$ at $20^{\circ} \mathrm{C}, \mathrm{L} 4$ $=0.5 \mathrm{MPa}$ at $75^{\circ} \mathrm{C}, \mathrm{L} 5=10 \mathrm{MPa}$ at $75^{\circ} \mathrm{C}, \mathrm{L} 6=0.5 \mathrm{MPa}$ at $95^{\circ} \mathrm{C}$, and $\mathrm{L} 7=10 \mathrm{MPa}$ at $95^{\circ} \mathrm{C}$. Protein bands are $\beta$-LG, $\alpha-\mathrm{LA}, \mathrm{IgG}$, lactoferrin $(\mathrm{LF}), \mathrm{BSA}, \alpha_{\mathrm{S}^{-}} \mathrm{CN}, \alpha_{\mathrm{S} 2}-\mathrm{CN}, \beta-\mathrm{CN}$, and $\kappa-\mathrm{CN}$.

concentration step, the zeta potential of SM or CSM did not change significantly $(P>0.05)$ after this treatment.

\section{Effects of Pressurized Thermal Processing at 75 and $95^{\circ} \mathrm{C}$ on Milk Proteins}

Examination of the effects of low pressure (10 MPa) on milk proteins at 75 or $95^{\circ} \mathrm{C}$ is the main focus of this section, and effect of temperature was considered when relevant. Thus, $10 \mathrm{MPa}$ was compared with $0.5 \mathrm{MPa}$ (0.5 $\mathrm{MPa}$ was considered the base pressure level) at each temperature level separately $\left(75\right.$ or $\left.95^{\circ} \mathrm{C}\right)$, where constant shearing $\left(1,000 \mathrm{~s}^{-1}\right)$ was also applied in all treatments. The average particle size of SM was slightly reduced after treatment at $10 \mathrm{MPa}$ and $75^{\circ} \mathrm{C}$ compared with $0.5 \mathrm{MPa}$ at $75^{\circ} \mathrm{C}$. On the other hand, the particle size significantly decreased in CSM subjected to $10 \mathrm{MPa}$ at $75^{\circ} \mathrm{C}$ compared with that treated at 0.5 $\mathrm{MPa}$ and $75^{\circ} \mathrm{C}$ (Table 1). A mostly similar trend was observed in both $\mathrm{SM}$ and $\mathrm{CSM}$ at $95^{\circ} \mathrm{C}$, as the particle size of the samples treated at $10 \mathrm{MPa}$ was reduced more than those subjected to 0.5 MPa pressure. Pressurization can substantially reduce casein micelle size due to compression, as observed in reconstituted SM after high-pressure and low-temperature treatments (100-200 MPa, 20 ${ }^{\circ} \mathrm{C}, 20 \mathrm{~min}$; Anema et al., 2005). Furthermore, increase in treatment temperature from 10 to $40^{\circ} \mathrm{C}$ at $100 \mathrm{MPa}$ exhibited a decreasing trend of micelle size (Anema et al., 2005). The micelle size of SM significantly increased when a range of high-pressure treatments $(200-800 \mathrm{MPa})$ were applied at $70^{\circ} \mathrm{C}$ for 30 min, compared with their counterparts at $20^{\circ} \mathrm{C}$, using a high-pressure processor equipped with a water jacket (Anema, 2008), potentially due to association of the denatured $\beta-\mathrm{LG}$ with the casein micelles (Huppertz et al., 2004b) or to the formation of large protein aggregates due to various interactions between caseins and whey proteins (Bogahawaththa et al., 2018). Hence, the observations in the current study suggest that the low-pressure, high-temperature treatments $(10 \mathrm{MPa}$, $\geq 5^{\circ} \mathrm{C}$ ) had effects on casein micelles similar to those 

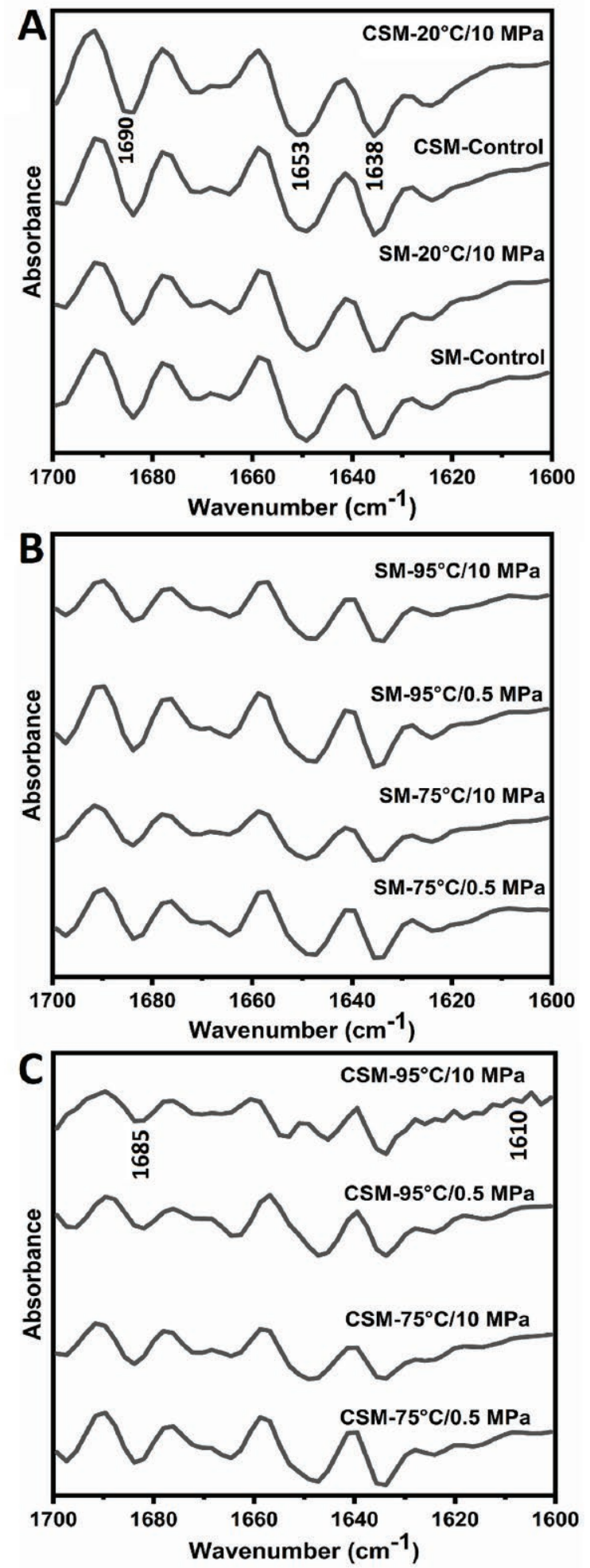

Figure 2. Second derivative of the Fourier-transform infrared spectra obtained from skim milk (SM) and concentrated skim milk (CSM) samples subjected to the different pressurized thermal treatments and their untreated controls (Control). (A) Control and samples of SM and $\mathrm{CSM}$ treated at $20^{\circ} \mathrm{C}$ and $10 \mathrm{MPa}$; (B) SM samples treated at 0.5 or $10 \mathrm{MPa}$ and at 75 or $95^{\circ} \mathrm{C}$; (C) CSM samples treated at 0.5 or $10 \mathrm{MPa}$ and at 75 or $95^{\circ} \mathrm{C}$ of high-pressure, low-temperature treatment (100 MPa, $20^{\circ} \mathrm{C}, \sim 20 \mathrm{~min}$ ) applied using HHP systems (Anema et al., 2005; Anema, 2008).

When comparing the protein bands between SM treated with $0.5 \mathrm{MPa}$ at $75^{\circ} \mathrm{C}$, versus $10 \mathrm{MPa}$ at $75^{\circ} \mathrm{C}$, and their serum phases, no substantial changes were observed for whey proteins in the nonreducing SDSPAGE images (Figure 1, A1, B1). However, we observed relatively intense $\alpha_{\mathrm{S1}^{-}}$and $\beta$-CN bands from the serum phase of SM treated with $10 \mathrm{MPa}$ at $75^{\circ} \mathrm{C}$, compared with those treated with $0.5 \mathrm{MPa}$ at $75^{\circ} \mathrm{C}$ (Figure 1, B1). A similar trend of results was observed between $\mathrm{SM}$ treated with $0.5 \mathrm{MPa}$ at $95^{\circ} \mathrm{C}$ and $10 \mathrm{MPa}$ at $95^{\circ} \mathrm{C}$ and their serum phases under nonreducing SDS-PAGE conditions. These intense casein bands observed at 10 $\mathrm{MPa}$, compared with $0.5 \mathrm{MPa}$, at 75 or $95^{\circ} \mathrm{C}$, can be related to further pressure-induced destabilization of the casein micelles and dissociation of the caseins due to solubilization of CCP and interruption of hydrogen bonds (Patel et al., 2006), which were also affected by heating (Anema, 1998). This observation appears to accord with an effect of the high-pressure, low-temperature treatments $\left(\geq 100 \mathrm{MPa}, 20^{\circ} \mathrm{C}, \sim 20 \mathrm{~min}\right)$ on the casein micelles (López-Fandiño et al., 1998a; Huppertz et al., 2004a; Anema et al., 2005).

Furthermore, no apparent changes in the $\alpha_{\mathrm{S} 1^{-}}$and $\beta$-CN bands were noticed between 75 and $95^{\circ} \mathrm{C}$ at each pressure level $(0.5$ or $10 \mathrm{MPa})$ in $\mathrm{SM}$, indicating heat stability of the micellar structure (Anema, 1998). However, the whey proteins in SM increasingly denatured at $95^{\circ} \mathrm{C}$, displaying substantially faint bands of $\beta-\mathrm{LG}$ and $\alpha$-LA as well as disappearance of BSA and IgG bands compared with those treated at $75^{\circ} \mathrm{C}$ (Bogahawaththa and Vasiljevic, 2020), without obvious pressure dependence, confirming their high heat-lability (Wijayanti et al., 2014, 2019). It also appeared that these whey proteins formed aggregates with the involvement of $\kappa$-CN at $95^{\circ} \mathrm{C}$, as seen on the stacking gel of the nonreducing SDS-PAGE (Figure 1, B1), which disappeared in the reducing gels (Figure 1, B2) due to reduction of the covalent bonds by $\beta$-mercaptoethanol. This confirmed that the protein aggregates were primarily formed by thiol (disulfide) bonds, as reported previously (Bogahawaththa and Vasiljevic, 2020). The formation of protein aggregates was also indicated by the substantially increased particle size in the $\mathrm{SM}$ samples treated at $95^{\circ} \mathrm{C}$ compared with those treated at $75^{\circ} \mathrm{C}$, and appeared to be pressure-dependent. The whey protein bands of CSM and its serum phase did not display substantial changes between 0.5 and $10 \mathrm{MPa}$ treatments at 75 or $95^{\circ} \mathrm{C}$, as indicated by the nonreducing SDS-PAGE images (Figure 1, C1 and D1).

The $\alpha_{\mathrm{S}^{-}}$and $\beta$-CN bands of the serum phase of CSM treated with $10 \mathrm{MPa}$ were more intense than those of 
the samples treated with $0.5 \mathrm{MPa}$ at 75 or $95^{\circ} \mathrm{C}$ (Figure $1, \mathrm{D} 1)$. Similar results were observed in the corresponding SM samples (with relatively faint bands due to the low protein concentration) and can be discussed in the same way in relation to the pressure-induced destabilization of the casein micelles. This also agrees with the substantially smaller average particle size of CSM treated at $10 \mathrm{MPa}$ compared with that treated at $0.5 \mathrm{MPa}$ at 75 or $95^{\circ} \mathrm{C}$. However, the $\alpha_{\mathrm{S}^{-}}$and $\beta-\mathrm{CN}$ bands of the serum phase of CSM treated at $75^{\circ} \mathrm{C}$ were prominent, whereas those treated at $95^{\circ} \mathrm{C}$ were relatively faint depending on the applied pressure. These casein bands in the serum phase of SM appeared to change depending only on the pressure $(0.5 \mathrm{MPa}$ vs. $10 \mathrm{MPa})$ but not the temperature levels $\left(75\right.$ and $\left.95^{\circ} \mathrm{C}\right)$. Markoska et al. (2019b) reported no changes in the $\alpha_{\mathrm{s}^{-}}$and $\beta-\mathrm{CN}$ bands of the serum phase when raw SM $(9 \% \mathrm{wt} / \mathrm{wt} \mathrm{TS})$ was heated from 75 to $110^{\circ} \mathrm{C}$, whereas intensity of these casein bands gradually reduced in the serum phase of the CSM (17 or $25 \%$ wt/wt TS) during the same heating ramp. This gradual reduction of $\alpha_{s}$ and $\beta$-CN bands in the serum phase of the CSM was ascribed to their reassociation with the casein micelles, which largely dissociated (reversibly) at $75^{\circ} \mathrm{C}$. Anema (1998) reported that when reconstituted CSM (17.5 or $25 \% \mathrm{wt} / \mathrm{wt} \mathrm{TS}$ ) was heated from 20 to $120^{\circ} \mathrm{C}$, the maximum dissociation of the casein micelles was observed at 60 to $80^{\circ} \mathrm{C}$, which resulted in the highest content of soluble $\alpha_{\mathrm{s}^{-}}$and $\beta-\mathrm{CN}$ in the serum phase. However, $\kappa-\mathrm{CN}$ progressively dissociated from the casein micelles with increase in temperature from 75 to $110^{\circ} \mathrm{C}$ in raw SM (Markoska et al., 2019b) and from 20 to $120^{\circ} \mathrm{C}$ in reconstituted SM (Anema, 1998) regardless of their TS (unconcentrated or concentrated), and formed soluble and insoluble aggregates with the involvement of the whey proteins, predominantly $\beta$-LG and $\alpha$-LA (Markoska et al., 2019b). A similar behavior was demonstrated by $\kappa-\mathrm{CN}$ in the current study. The $\kappa-\mathrm{CN}$ band in the serum phase of $\mathrm{SM}$ or CSM treated at $95^{\circ} \mathrm{C}$ was more intense, due to disintegration of thiol (disulfide)linked $\kappa-\mathrm{CN}$ and whey-protein soluble aggregates, than those treated at $75^{\circ} \mathrm{C}$, depending on the pressure applied (Figure 1, B2, D2).

The Fourier-transform infrared spectrometry results of SM and CSM demonstrated substantial reduction of $\beta$-sheet and $\alpha$-helix structural elements in the samples treated at $10 \mathrm{MPa}$ compared with the $0.5 \mathrm{MPa}$ treatment at 75 or $95^{\circ} \mathrm{C}$ (Figure 2, B, C). This could be ascribed mainly to loss of native confirmation of the whey proteins, as observed previously, after the highpressure, low-temperature treatments $(\geq 100 \mathrm{MPa}$, 20-30 ${ }^{\circ} \mathrm{C}, \sim 20 \mathrm{~min}$; Maresca et al., 2017; Bogahawaththa et al., 2018). Treatment of CSM with $10 \mathrm{MPa}$ at $95^{\circ} \mathrm{C}$ resulted in a relatively greater loss of $\alpha$-helices and appearance of a few new peaks in the $\beta$-sheet region $\left(\sim 1638-1,610 \mathrm{~cm}^{-1}\right.$; Bogahawaththa et al., 2019), displaying some molecular rearrangements. We found no major changes $(P>0.05)$ in zeta potential between SM or CSM treated with $0.5 \mathrm{MPa}$ and $10 \mathrm{MPa}$ at 75 or $95^{\circ} \mathrm{C}$. However, SM and CSM had slightly less negative surface potential after treatment at $10 \mathrm{MPa}$ and $95^{\circ} \mathrm{C}$ compared with those of the control, indicating protein aggregation mainly induced by elevated temperature and shearing (Mediwaththe et al., 2018b), as observed from the nonreducing SDS-PAGE.

The pressure applied (10 MPa) did not modify the mineral balance of SM or CSM significantly at 75 or $95^{\circ} \mathrm{C}$ (except $\mathrm{Mg}$ in $\mathrm{SM}$ at $95^{\circ} \mathrm{C}$ and $\mathrm{P}$ in $\mathrm{CSM}$ at

Table 2. The total and soluble mineral concentration of skim milk and concentrated skim milk samples subjected to different pressurized thermal treatments

\begin{tabular}{|c|c|c|c|c|c|c|}
\hline Sample & $\begin{array}{l}\text { Temperature } \\
\left({ }^{\circ} \mathrm{C}\right)\end{array}$ & $\begin{array}{l}\text { Pressure } \\
(\mathrm{MPa})\end{array}$ & & \multicolumn{3}{|c|}{ Mineral concentration $(\mathrm{m} M)$} \\
\hline \multirow{4}{*}{$\begin{array}{l}\text { Skim milk } \\
(\sim 9 \% \mathrm{wt} / \text { wt total solids })\end{array}$} & Control $(\sim 20)$ & $\mathrm{NA}^{1}$ & Total minerals & $35.2 \pm 2.2$ & $5.2 \pm 0.2$ & $30.5 \pm 1.4$ \\
\hline & 20 & 10 & & $10.6 \pm 0.1^{\mathrm{ef}}$ & $3.0 \pm 0.0^{\mathrm{bc}}$ & $11.8 \pm 0.0^{\mathrm{f}}$ \\
\hline & 75 & 0.5 & & $10.0 \pm 0.3^{\mathrm{f}}$ & $3.1 \pm 0.0^{\mathrm{b}}$ & $11.7 \pm 0.3^{\mathrm{f}}$ \\
\hline & 75 & 10 & & $10.1 \pm 0.1^{\mathrm{f}}$ & $2.9 \pm 0.1^{\mathrm{bc}}$ & $11.6 \pm 0.1^{\mathrm{f}}$ \\
\hline \multirow{7}{*}{$\begin{array}{l}\text { Concentrated skim milk } \\
(\sim 22 \% \text { wt/wt total solids })\end{array}$} & Control $(\sim 20)$ & NA & Total minerals & $81.8 \pm 1.6$ & $12.3 \pm 0.2$ & $72.6 \pm 1.8$ \\
\hline & Control $(\sim 20)$ & NA & Soluble minerals & $33.1 \pm 1.1^{\mathrm{a}}$ & $8.3 \pm 0.1^{\mathrm{ab}}$ & $35.4 \pm 0.8^{\circ}$ \\
\hline & 20 & 10 & & $29.5 \pm 0.8^{\mathrm{b}}$ & $8.1 \pm 0.1^{\mathrm{bc}}$ & $32.4 \pm 0.7^{\natural}$ \\
\hline & 75 & 0.5 & & $30.5 \pm 0.9^{\mathrm{b}}$ & $8.4 \pm 0.3^{\mathrm{ab}}$ & $33.3 \pm 0.4^{h}$ \\
\hline & 75 & 10 & & $30.3 \pm 0.6^{\mathrm{b}}$ & $8.4 \pm 0.0^{\mathrm{a}}$ & $35.2 \pm 0.4^{2}$ \\
\hline & 95 & 0.5 & & $22.9 \pm 1.2^{\mathrm{c}}$ & $7.9 \pm 0.2^{\mathrm{c}}$ & $28.8 \pm 0.7^{\circ}$ \\
\hline & 95 & 10 & & $21.8 \pm 0.7^{\mathrm{c}}$ & $7.5 \pm 0.1^{\mathrm{c}}$ & $29.1 \pm 0.3^{c}$ \\
\hline
\end{tabular}

\footnotetext{
${ }^{\mathrm{a}-\mathrm{f}}$ The mean values of the same soluble mineral without a common superscript letter indicate significant difference $(P \leq 0.05)$.

${ }^{1} \mathrm{NA}=$ not applicable.
} 
$75^{\circ} \mathrm{C}$ ), compared with that at $0.5 \mathrm{MPa}$, although the casein micelle was substantially altered in the current study in a similar way as if it were subjected to a highpressure, low-temperature treatment $\left(\geq 100 \mathrm{MPa}, 20^{\circ} \mathrm{C}\right.$, $\sim 20 \mathrm{~min})$. High-pressure treatments at $\geq 100 \mathrm{MPa}$ and $20^{\circ} \mathrm{C}$ for 15 to $30 \mathrm{~min}$ resulted in an increase in soluble minerals $(\mathrm{Ca}, \mathrm{P}$, and $\mathrm{Mg}$ ) in the serum phase of $\mathrm{SM}$ (López-Fandiño et al., 1998a) and reconstituted milk protein concentrates (Cadesky et al., 2017), due to disintegration of the casein micelles and movement of $\mathrm{Ca}, \mathrm{P}$, and $\mathrm{Mg}$ into the serum phase. In contrast, heat treatment can result in movement of the mineral balance into the micellar phase mainly by association of $\mathrm{Ca}$ and $\mathrm{P}$ with the casein micelles (Gaucheron, 2005). We observed a substantial reduction of $\mathrm{Ca}, \mathrm{P}$, and $\mathrm{Mg}$ in the serum phase of SM and CSM with increase in treatment temperature from 20 to $95^{\circ} \mathrm{C}$, regardless of the pressure applied; this effect was greater in CSM than in SM, as observed previously (Markoska et al., $2019 \mathrm{~b})$. Hence, the effect of low pressure (10 MPa) on the mineral balance in SM and CSM appeared to be mostly counterbalanced by the effect of temperature $\left(75\right.$ or $95^{\circ} \mathrm{C}$ ) in the current study.

The heat and pressure treatments govern denaturation of the whey proteins differently in the milk. The heat-induced denaturation of whey proteins occurs following increased hydrophobic interactions and reduction of soluble $\mathrm{Ca}$ and $\mathrm{P}$ in the serum phase. On the contrary, the pressure treatments induce denaturation of the whey proteins through diminished hydrophobic interactions and increased solubility of $\mathrm{Ca}$ and $\mathrm{P}$ (Anema, 2008). Because the temperature levels were more severe than the pressure applied in the current study, in terms of denaturation of whey proteins (Huppertz et al., 2004b; Patel et al., 2006), the influence of low pressure $(10 \mathrm{MPa})$ on denaturation of whey proteins appeared to be offset by the effect of the high temperature $\left(75\right.$ or $\left.95^{\circ} \mathrm{C}\right)$. Hence, in the current study, we observed that the increase in temperature from 20 to $95^{\circ} \mathrm{C}$ accelerated the denaturation of $\beta-\mathrm{LG}, \alpha-\mathrm{LA}, \mathrm{IgG}$, $\mathrm{LF}$, and BSA, whereas we detected no significant effect of $10 \mathrm{MPa}$ on denaturation of these whey proteins at 75 or $95^{\circ} \mathrm{C}$, as previously discussed.

\section{CONCLUSIONS}

All the variables tested had individual or combined effects on native milk proteins. Evaporative concentration resulted in the destabilization of the casein micelles and dissociation of $\alpha_{S^{-}}$and $\beta$-casein into the serum phase. Generally, CSM appeared to be more prone to further modifications than SM. Pressurized shearing at $20^{\circ} \mathrm{C}$ contributed to formation of soluble aggregates in CSM, driven mainly by dissociated caseins and minor whey proteins. Temperatures of 75 and $95^{\circ} \mathrm{C}$ influenced the caseins, whey proteins, and mineral balance, whereas low pressure (10 MPa) appeared to influence the micellar structure regardless of temperature. Treatment of $10 \mathrm{MPa}$ at 75 or $95^{\circ} \mathrm{C}$ can result in dissociation of casein micelles and reduction of their size in both SM and CSM, mostly in a similar way to that found in a high-pressure, low-temperature treatment $(\geq 100$ $\left.\mathrm{MPa}, 20^{\circ} \mathrm{C}, \sim 20 \mathrm{~min}\right)$. However, the applied pressure did not greatly modify the mineral balance or accelerate denaturation of whey proteins, due to a countereffect exerted by heating. The pressurization contributed to substantial loss of the secondary structure during shearing at $20^{\circ} \mathrm{C}$ and heating at 75 or $95^{\circ} \mathrm{C}$. These results need to be considered for optimum processing of dairy systems.

\section{ACKNOWLEDGMENTS}

The authors have not stated any conflicts of interest.

\section{REFERENCES}

Anema, S. G. 1998. Effect of milk concentration on heat-induced, pHdependent dissociation of casein from micelles in reconstituted skim milk at temperatures between 20 and $120^{\circ} \mathrm{C}$. J. Agric. Food Chem. 46:2299-2305. https://doi.org/10.1021/jf970909+.

Anema, S. G. 2008. Heat and/or high-pressure treatment of skim milk: Changes to the casein micelle size, whey proteins and the acid gelation properties of the milk. Int. J. Dairy Technol. 61:245-252. https://doi.org/10.1111/j.1471-0307.2008.00418.x.

Anema, S. G., and H. Klostermeyer. 1997. Heat-induced, pH-dependent dissociation of casein micelles on heating reconstituted skim milk at temperatures below $100^{\circ}$ C. J. Agric. Food Chem. 45:11081115. https://doi.org/10.1021/jf960507m.

Anema, S. G., E. K. Lowe, and R. Stockmann. 2005. Particle size changes and casein solubilisation in high-pressure-treated skim milk. Food Hydrocoll. 19:257-267. https://doi.org/10.1016/j .foodhyd.2004.04.025.

Bogahawaththa, D., R. Buckow, J. Chandrapala, and T. Vasiljevic. 2018. Comparison between thermal pasteurization and high pressure processing of bovine skim milk in relation to denaturation and immunogenicity of native milk proteins. Innov. Food Sci. Emerg. Technol. 47:301-308. https://doi.org/10.1016/j.ifset.2018.03.016.

Bogahawaththa, D., J. Chandrapala, and T. Vasiljevic. 2017. Thermal denaturation of bovine immunoglobulin $\mathrm{G}$ and its association with other whey proteins. Food Hydrocoll. 72:350-357. https://doi.org/ 10.1016/j.foodhyd.2017.06.017.

Bogahawaththa, D., J. Chandrapala, and T. Vasiljevic. 2019. Thermal denaturation of bovine $\beta$-lactoglobulin in different protein mixtures in relation to antigenicity. Int. Dairy J. 91:89-97. https://doi .org/10.1016/j.idairyj.2018.10.004.

Bogahawaththa, D., and T. Vasiljevic. 2020. Shearing accelerates denaturation of $\beta$-lactoglobulin and $\alpha$-lactalbumin in skim milk during heating. Int. Dairy J. 105:104674. https://doi.org/10.1016/j .idairyj.2020.104674.

Bylund, G. 2003. Dairy Processing Handbook. Tetra Pak Processing Systems AB, Lund, Sweden.

Cadesky, L., M. Walkling-Ribeiro, K. T. Kriner, M. V. Karwe, and C. I. Moraru. 2017. Structural changes induced by high-pressure processing in micellar casein and milk protein concentrates. J. Dairy Sci. 100:7055-7070. https://doi.org/10.3168/jds.2016-12072.

Deeth, H. C., and N. Datta. 2011. Heat treatment of milk: Ultra-high temperature treatment (UHT): Heating systems. Pages 699-707 
in Encyclopedia of Dairy Sciences, second ed. J. W. Fuquay, P. F. Fox, and P. L. H. McSweeney, ed. Academic Press, London, UK.

Gaucheron, F. 2005. The minerals of milk. Reprod. Nutr. Dev. 45:473483. https://doi.org/10.1051/rnd:2005030.

Huppertz, T. 2016. Heat stability of milk. Pages 179-196 in Advanced Dairy Chemistry. P. L. H. McSweeney and J. A. O'Mahony, ed. Springer, New York, NY.

Huppertz, T., P. F. Fox, and A. L. Kelly. 2004a. Dissociation of caseins in high pressure-treated bovine milk. Int. Dairy J. 14:675-680. https://doi.org/10.1016/j.idairyj.2003.11.009.

Huppertz, T., P. F. Fox, and A. L. Kelly. 2004b. High pressure treatment of bovine milk: Effects on casein micelles and whey proteins. J. Dairy Res. 71:97-106. https://doi.org/10.1017/ S002202990300640X.

Huppertz, T., T. Vasiljevic, B. Zisu, and H. C. Deeth. 2019. Novel processing technologies: Effects on whey protein structure and functionality. Pages 281-334 in Whey Proteins. H. C. Deeth and N. Bansal, ed. Elsevier, Amsterdam, the Netherlands.

Lefèvre, T., and M. Subirade. 1999. Structural and interaction properties of $\beta$-Lactoglobulin as studied by FTIR spectroscopy. Int. J. Food Sci. Technol. 34:419-428. https://doi.org/10.1046/j.1365 $-2621.1999 .00311 . x$.

López-Fandiño, R., M. A. De la Fuente, M. Ramos, and A. Olano. 1998a. Distribution of minerals and proteins between the soluble and colloidal phases of pressurized milks from different species. J. Dairy Res. 65:69-78. https://doi.org/10.1017/S0022029997002653.

López-Fandiño, R., and A. Olano. 1998b. Effects of high pressures combined with moderate temperatures on the rennet coagulation properties of milk. Int. Dairy J. 8:623-627. https://doi.org/10 .1016/S0958-6946(98)00093-4.

Maresca, P., G. Ferrari, B. R. C. Leite Júnior, L. M. Zanphorlin, L. R. Ribeiro, M. T. Murakami, and M. Cristianini. 2017. Effect of dynamic high pressure on functional and structural properties of bovine serum albumin. Food Res. Int. 99:748-754. https://doi.org/ 10.1016/j.foodres.2017.06.047.

Markoska, T., T. Huppertz, M. K. Grewal, and T. Vasiljevic. 2019a. FTIR analysis of physiochemical changes in raw skim milk upon concentration. Lebensm. Wiss. Technol. 102:64-70. https://doi .org/10.1016/j.lwt.2018.12.011.

Markoska, T., T. Huppertz, M. K. Grewal, and T. Vasiljevic. 2019b. Structural changes of milk proteins during heating of concentrated skim milk determined using FTIR. Int. Dairy J. 89:21-30. https:/ /doi.org/10.1016/j.idairyj.2018.08.010.

Mediwaththe, A., D. Bogahawaththa, M. K. Grewal, J. Chandrapala, and T. Vasiljevic. 2018a. Structural changes of native milk proteins subjected to controlled shearing and heating. Food Res. Int 114:151-158. https://doi.org/10.1016/j.foodres.2018.08.001.

Mediwaththe, A., J. Chandrapala, and T. Vasiljevic. 2018b. Shearinduced behaviour of native milk proteins heated at temperatures above $80^{\circ} \mathrm{C}$. Int. Dairy J. 77:29-37. https://doi.org/10.1016/j .idairyj.2017.09.002.

Nieuwenhuijse, J., W. Timmermans, and P. Walstra. 1988. Calcium and phosphate partitions during the manufacture of sterilized concentrated milk and their relations to the heat stability. Neth. Milk Dairy J. 42:387-421.

Nunes, L., and G. M. Tavares. 2019. Thermal treatments and emerging technologies: Impacts on the structure and techno-functional properties of milk proteins. Trends Food Sci. Technol. 90:88-99. https://doi.org/10.1016/j.tifs.2019.06.004.

Patel, H. A., H. Singh, S. G. Anema, and L. K. Creamer. 2006. Effects of heat and high hydrostatic pressure treatments on disulfide bonding interchanges among the proteins in skim milk. J. Agric. Food Chem. 54:3409-3420. https://doi.org/10.1021/jf052834c.

Wijayanti, H. B., N. Bansal, and H. C. Deeth. 2014. Stability of whey proteins during thermal processing: A review. Compr. Rev. Food Sci. Food Saf. 13:1235-1251. https://doi.org/10.1111/1541-4337 .12105 .

Wijayanti, H. B., A. Brodkorb, S. A. Hogan, and E. G. Murphy. 2019. Thermal denaturation, aggregation, and methods of prevention. Pages 185-247 in Whey Proteins. H. C. Deeth and N. Bansal, ed. Elsevier, Amsterdam, the Netherlands. 